\title{
Geotechnical Study of the Aptian Limestone of the Kef Region, Northwestern Tunisia: Evaluation for Industrial Use
}

\author{
Imed Ben Salah*, Moufida Ben M'Barek Jemaï, Safa Mezza, Mabrouk Boughdiri \\ Department of Geology, Sciences University of Bizerte, University of Carthage, Bizerte, Tunisia \\ Email: ^Imed_bensalah@yahoo.fr
}

How to cite this paper: Salah, I.B., Ben M'Barek Jemaï, M., Mezza, S. and Boughdiri, M. (2018) Geotechnical Study of the Aptian Limestone of the Kef Region, Northwestern Tunisia: Evaluation for Industrial Use. Open Journal of Geology, 8, 1084-1101.

https://doi.org/10.4236/ojg.2018.812066

Received: December 31, 2016

Accepted: November 6, 2018

Published: November 9, 2018

Copyright $\odot 2018$ by authors and Scientific Research Publishing Inc. This work is licensed under the Creative Commons Attribution International License (CC BY 4.0).

http://creativecommons.org/licenses/by/4.0/ (c) $(7)$

\begin{abstract}
This study aims to the initial characterization of Aptian sedimentary limestones in the Kef region located in the North-West of Tunisia in order to use in industrial fields. The limestone samples were collected from three outcrops respectively named Jebel Jerissa, Jebel Hmeima and Jebel Harraba. A geochemical characterization highlights a variation of the weight percentage (wt\%) as follows: $\mathrm{CaO}$ (53 - 55), $\mathrm{MgO}(0.04-0.28), \mathrm{Al}_{2} \mathrm{O}_{3}(0.07-0.51), \mathrm{Fe}_{2} \mathrm{O}_{3}$ (0.41 - 2.87), and a loss on ignition (41.62 - 43.35). The other oxides $\left(\mathrm{K}_{2} \mathrm{O}\right.$, $\left.\mathrm{SO}_{3}, \mathrm{Na}_{2} \mathrm{O}\right)$ are in trace amounts. Mineralogical analysis revealed that limestones contain more than $95 \%$ of calcite and the clay impurities are the minor phases detected. Petrographic study showed that these limestones are packestone-wakestone type. The hardness of Aptian limestones crosses the upper limit of the hard domain. Geotechnical tests reveal a Dry Micro Deval (MDS) coefficient varying from $23 \%$ to $33 \%$, a Wet Micro Deval (MDH) coefficient with values oscillating around $26 \%$ to $36 \%$, a Los Angeles coefficient (LA) about 25\% against a value of the compressive strength ranging from 593 $\mathrm{Kg} / \mathrm{cm}^{2}$ to $866 \mathrm{Kg} / \mathrm{cm}^{2}$. The gravimetric tests highlighted a flexural strength value from $106 \mathrm{Kg} / \mathrm{cm}^{2}$ at $208 \mathrm{Kg} / \mathrm{cm}^{2}$, while the ultrasonic coefficient oscillates from $4876 \mathrm{~m} / \mathrm{s}$ to $5233 \mathrm{~m} / \mathrm{s}$, indicating the low porosity of these limestone $(0.5 \%$ to $1 \%)$. The density recorded an average value of $2.50 \mathrm{~g} / \mathrm{cm}^{3}$. The various properties studied have proved that the limestone studied can be used in various industrial fields such steel industry, aggregate, cement industry and marble.
\end{abstract}

\section{Keywords}

Aptian Limestone, Geotechnical Properties, Geochemical Properties, Industrial Use 


\section{Introduction}

Since the works of [1] and his successors, mainly most of them [2] [3] and [4], particular attention has been paid to the series of central and northern Tunisia of the Algerian-Tunisian borders. These series show impressive sedimentary accumulations during the Aptian-Albian periods. [2] describes the Aptian succession exceeding $2200 \mathrm{~m}$ thick at the Algerian-Tunisian borders. Impressive calcareous series [5] appears similar throughout the area, such as the "Limestones of Serdj" which have been deposited in certain sectors. These carbonate series belong to a vast platform that extended throughout Central Tunisia [6] and a large part of Northern Tunisia (Slata, Djerissa, Hameïma, Harraba, Boulahnèche...). We selected three study sites in the Kef area: the Hameïma, Djerissa and Harraba deposits, which will be the subject of a petrographic and geotechnical study. This area are located between $35^{\circ} 15^{\prime}$ to the south and $36^{\circ} 8^{\prime}$ to the north and meridians $8^{\circ} 47^{\prime}$ to the east and $8^{\circ} 18^{\prime}$ to the west (Figure 1), belongs to the topographic set of Upper Tell [7] marked by a limestone and marl-limestone geological substratum. Despite the number of studies launched in the extreme north Western Tunisia [8] [9], physicochemical and geotechnical characterization of Aptian limestones and their behavior remain unknown. The Aptian limestones

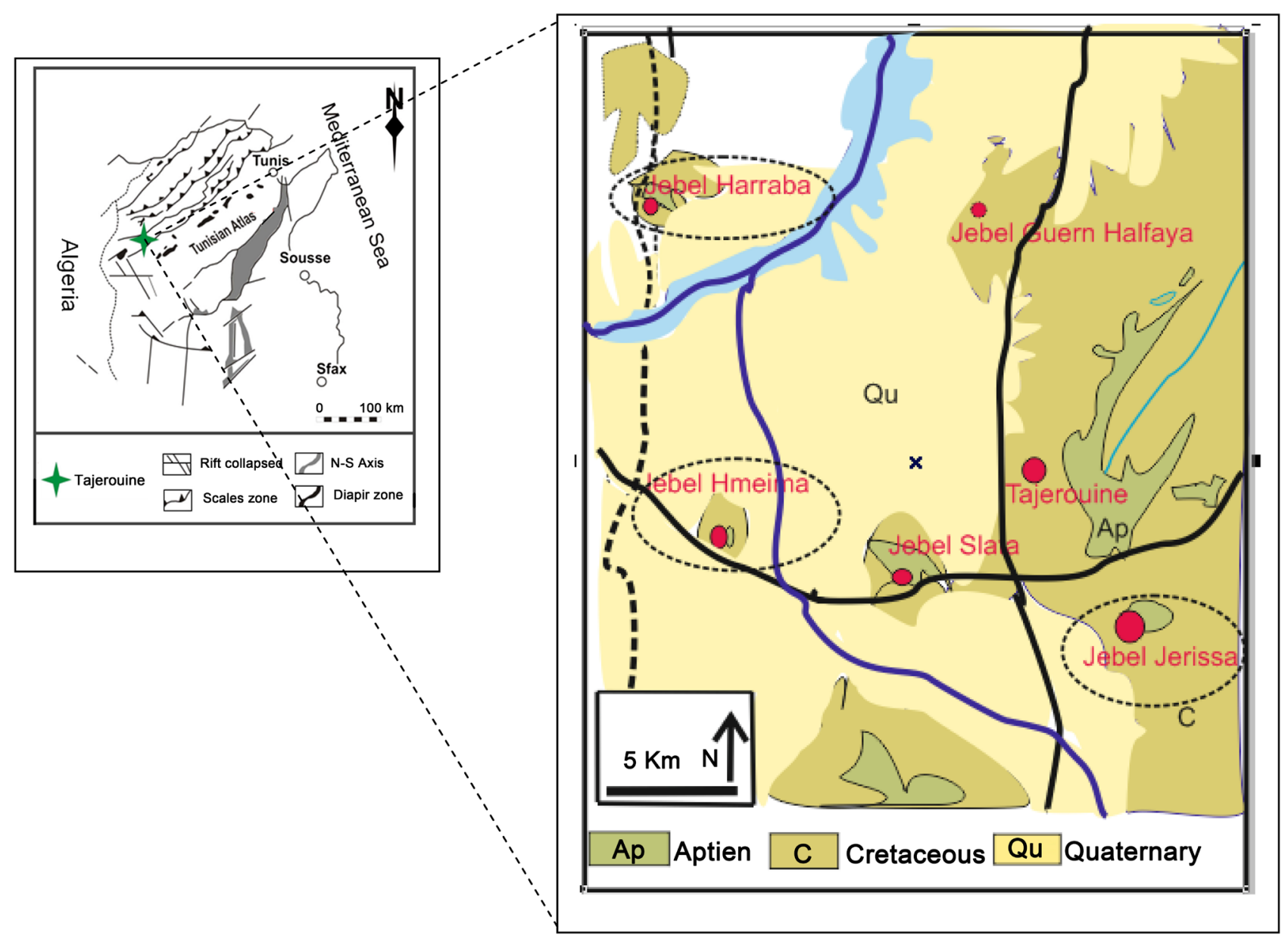

Figure 1. Location of the study area. 
of the Kef area have been studied for possible use in the industrial field. The study was carried out on forty-five samples taken from the blackish gray limestone deposit of Hmeima, the deposit of Jebel Harraba and the massif of Jerissa

(Figure 2).

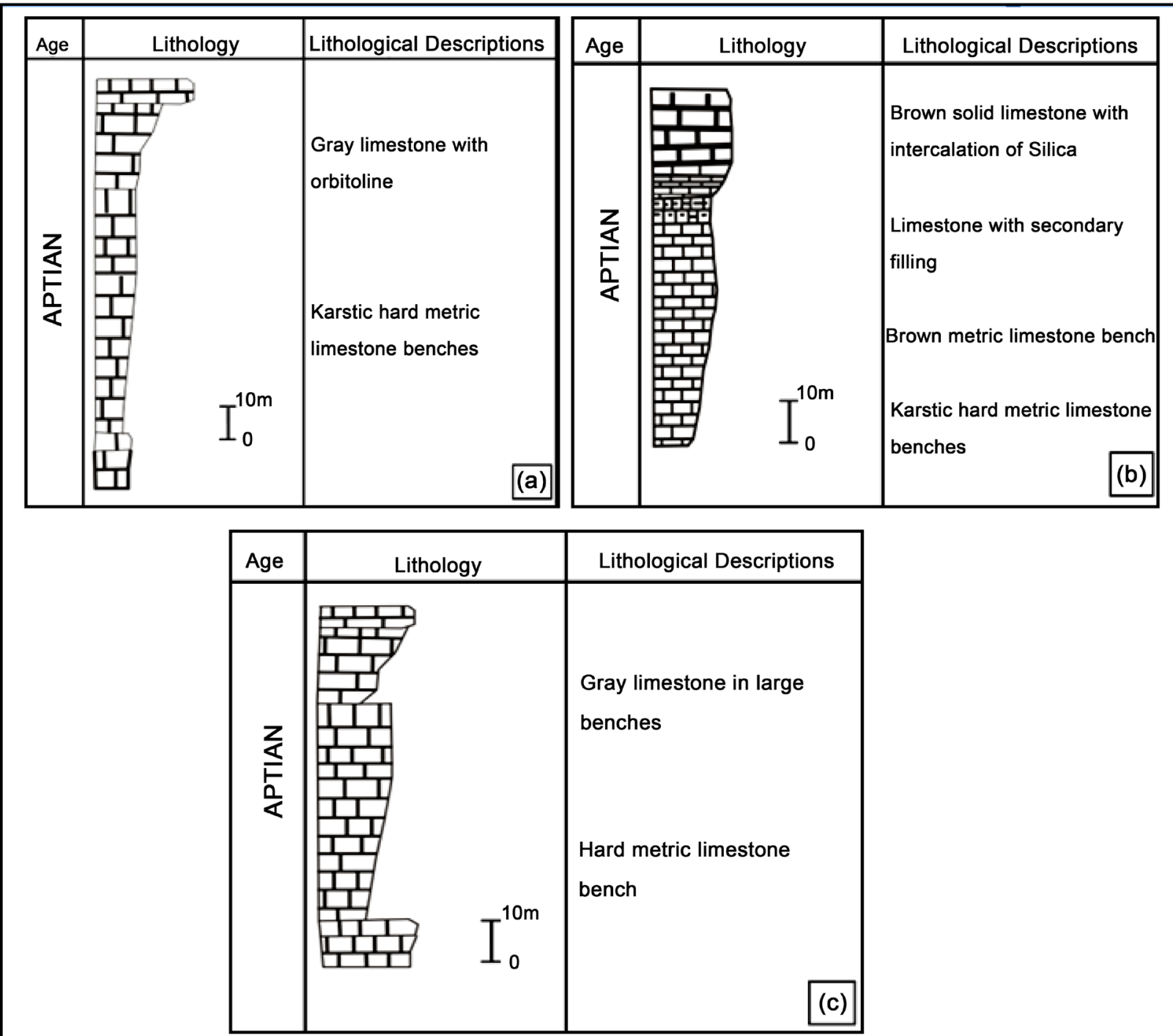

Figure 2. Stratigraphical description of J. Hmeima (a), Harraba (b) and Jerissa (c).

\section{Materials and Methods}

The available methods for sustainability study are described in Figure 3.

The chemical analysis of the major elements of the useful materials was assayed using the Atomic Absorption Spectrometry technique, which applied to the determination of the content of a sample in $\mathrm{CaO}, \mathrm{MgO}, \mathrm{Al}_{2} \mathrm{O}_{3}, \mathrm{MgO}, \mathrm{Fe}_{2} \mathrm{O}_{3}$, $\mathrm{Na}_{2} \mathrm{O}$ and $\mathrm{K}_{2} \mathrm{O}$. Sulfates were determined by conventional dosage and the gravimetric method for evaluating the weight loss of material after firing at $1000^{\circ} \mathrm{C}$. The mineralogical analysis was performed using an X-ray diffraction device based on the diffraction of a monochromatic X-ray beam according to Bragg's 


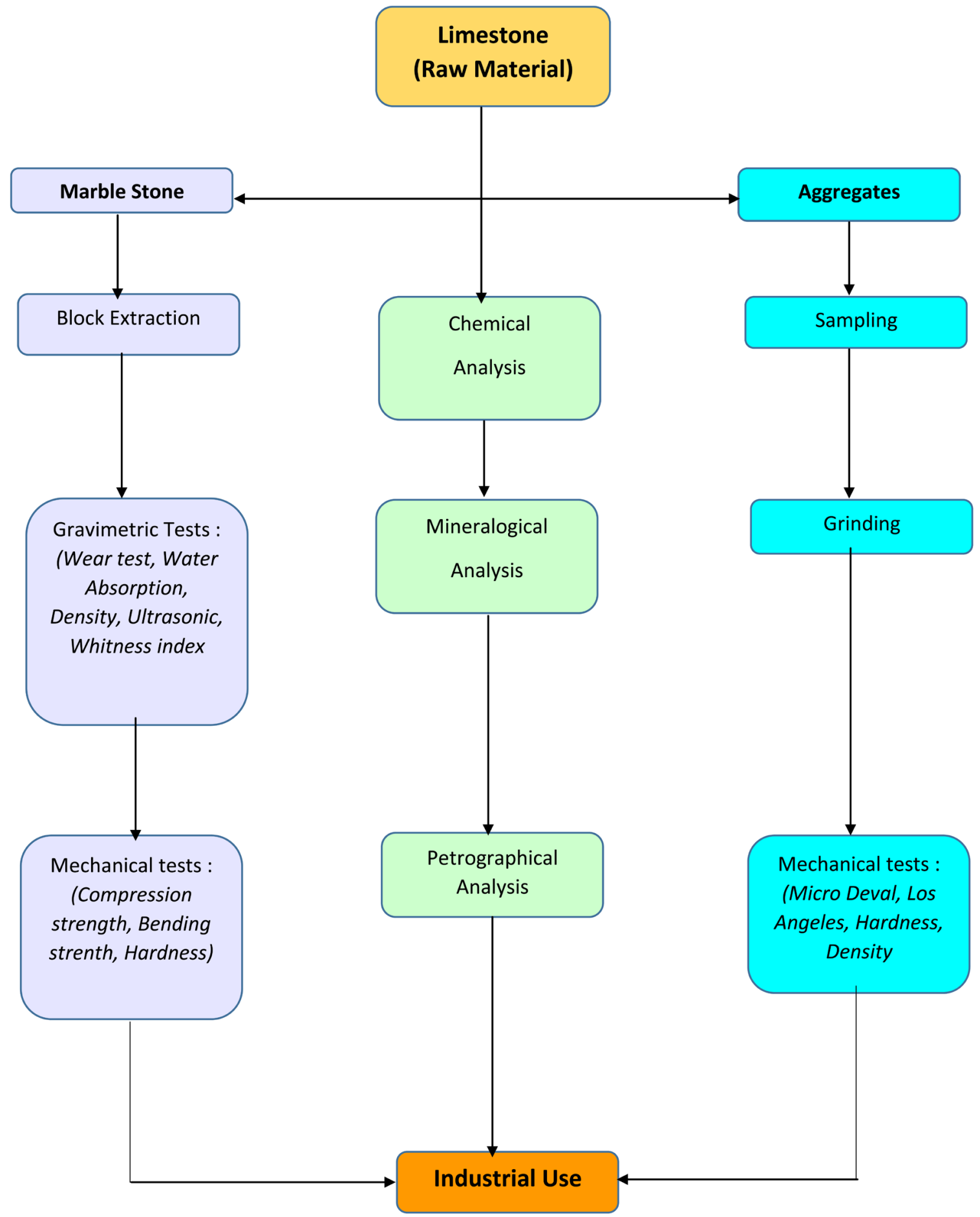

Figure 3. Methodology for limestone’s study.

law. An X-ray diffraction analysis was performed on all samples of total limestone based on the use of a Philips X'Pert PRO diffractometer $(\mathrm{CuKa}, \lambda=$ $0.154056 \mathrm{~nm}, 2 \theta$ Range $\left.3^{\circ}-60^{\circ}\right)$. Gravimetric testing of marble stone began with the sampling and extraction of blocks. Different block were extracted according to specimens with well-defined dimensions (Table 1). 
Table 1. Dimensions of test specimens for marble stones.

\begin{tabular}{cccc}
\hline & Shape of the test piece & Dimension $(\mathrm{cm})$ & Number of tested pieces \\
\hline Compression test & Cube & $7 \times 7 \times 7$ & 3 \\
Bending test & Plate & $22 \times 10 \times 5$ & 3 \\
Wear test & Plate & $10 \times 10 \times 3$ & 3 \\
Water absorption test & Cube & $7 \times 7 \times 7$ & 5 \\
Impact test & Plate & $20 \times 20 \times 3$ & 3 \\
Real density & Cube & $7 \times 7 \times 7$ & 3 \\
Apparent density & Cube & $7 \times 7 \times 7$ & 3 \\
Ultrasonic testing & Prism & $7 \times 7 \times 28$ & 3 \\
Porosity test & Cube & $7 \times 7 \times 7$ & 3 \\
\hline
\end{tabular}

The compression strength test was carried out according to [10]. It's consists of the measurement of the resistance of the rock to crushing by progressively applying the pressure up to the break of the specimen. The test was carried out by a hydraulic press. The bending test was carried out according to [11] and consists of the measurement of the resistance of the rock to loads when it is placed above a vacuum when we applied load with an effort of $0.2 \mathrm{~N} / \mathrm{mm}^{2}$ per second. The real density determines the degree of compactness of the rock. The impact strength was determined according to the standard [12] and consisted in dropping a ball that weighs $1 \mathrm{~kg}$ attached to a wire. This mass will be released at different heights until the specimen breaks. The resistance of abrasion was achieved according to standard [13] and consists in determining the length of the print produced on the specimen by the edge of a metal disc rotating under specified conditions in the presence of abrasive material. The porosity test was carried out according to the standard [14] and aims to know the ratio of the voids in a rock. The Apparent and real densities was carried out according to standard [14]. The test samples used are dried before use at a temperature of $80{ }^{\circ} \mathrm{C}$ to a constant weight. The ultrasonic test is carried out in accordance with the requirements of [15]. The result defines the propagation velocity of a sonic wave across the rock.

For aggregate tests, sampling was carried out according to [16], which applies to all aggregates used for civil engineering (concrete, asphalt, surface coatings, etc.). To comply with the rules of sampling a corridor divider was used. The Los Angeles test was carried out in accordance with standard [17] and aims to determine the resistance to fragmentation of a sample of aggregate. It consists on measuring the amount of element less than $1.6 \mathrm{~mm}$ produced by subjecting the material to a series of friction shocks in the Los Angeles apparatus which consist of a cylinder measured inside (508 \pm 5$) \mathrm{mm}$ and has a diameter of $(711 \pm 5 \mathrm{~mm})$ and is manufactured with a $12 \mathrm{~mm}$ thick sheet. The Micro Deval test defines the wear resistance of a granulate sample according to [18]. The Micro-Deval abrasion test is a test of fine aggregate to determine abrasion loss in the presence of 
water and an abrasive charge. The Micro Deval apparatus consists of a number of test cylinders having a diameter of $(200 \pm 1) \mathrm{mm}$ and an inside length of (154 $\pm 1) \mathrm{mm}$, watertight and laid on two horizontal supports driven by a motor rotating $(100 \pm 5) \mathrm{rpm}$. The stainless steel balls used have a diameter of $10 \pm 0.5$ $\mathrm{mm}$. The tests can be carried out dry or wet. The density and absorption coefficient are determined by the pycnometer method for aggregates in accordance with [19]. The petrographic study of limestones was based on the two facies description nomenclatures, combining the nature of the constituents of the rock: cement, matrix and porous space [20] with the percentage of elements represented by (Mudstone: $<5 \%$ allochems, wackestone: $>5 \%$ allochems, packstone and grainstone: Allochems joined) [21]. This study is carried out at laboratory and consists essentially of the observation by means of a Zeiss Axiosskop 40 microscope using polarized light. The interpretation of the micro facies identified was done through thin sections.

\section{Results and Discussion}

\subsection{Chemical Analysis of Deposits in the Kef Region}

Chemical analysis of Aptian limestones in the Kef area is presented in Table 2.

Chemical analysis of Aptian limestones (J.Harraba, J.Hmeima and J.Jerissa) showed a similarity in geochemical distribution by recording a percentage of $\mathrm{CaO}$ varying from $41 \%$ to $43 \%$ for all outcrops, a low content of $\mathrm{Fe}_{2} \mathrm{O}_{3}$ with the exception of Jebel Jerissa (2\%), infinitesimal contents for other oxides such as $\mathrm{MgO}, \mathrm{Na}_{2} \mathrm{O}$ and $\mathrm{K}_{2} \mathrm{O}$. The loss on ignition was $42 \%$, indicating a chemical purity of these limestones. These results are confirmed by the mineralogical analysis (Figure 4), where the $\mathrm{XRD}$ patterns show a very high content of $\mathrm{CaCO}_{3}$ (with an average of $95.80 \%$ ) with low impurity contents.

Table 2. Chemical results of the Aptian limestone of the Kef area.

\begin{tabular}{ccccccccc}
\hline Samples & L.O.I & $\mathrm{CaO}$ & $\mathrm{Fe}_{2} \mathrm{O}_{3}$ & $\mathrm{SiO}_{2}$ & $\mathrm{Al}_{2} \mathrm{O}_{3}$ & $\mathrm{MgO}$ & $\mathrm{Na}_{2} \mathrm{O}$ & $\mathrm{K}_{2} \mathrm{O}$ \\
\hline Har 1 & 45.30 & 53.1 & 0.29 & 0.95 & 0.2 & 0.14 & 0.01 & 0.01 \\
Har 2 & 45.36 & 52.76 & 0.26 & 1.05 & 0.3 & 0.25 & 0.01 & 0.01 \\
Har 3 & 45.44 & 52.34 & 0.32 & 1.4 & 0.23 & 0.23 & 0.01 & 0.03 \\
Har 4 & 44.56 & 52.32 & 0.95 & 1.6 & 0.35 & 0.18 & 0.02 & 0.02 \\
Har 5 & 44.13 & 53.22 & 0.82 & 1.2 & 0.35 & 0.24 & 0.02 & 0.02 \\
Har 6 & 44.25 & 53.15 & 0.74 & 1.2 & 0.35 & 0.28 & 0.02 & 0.01 \\
Har 7 & 43.03 & 54.13 & 0.95 & 1.23 & 0.3 & 0.25 & 0.08 & 0.03 \\
Har 8 & 43.14 & 54.18 & 0.84 & 1.23 & 0.3 & 0.28 & 0.02 & 0.01 \\
Har 9 & 43.00 & 54.25 & 0.75 & 1.31 & 0.36 & 0.29 & 0.01 & 0.03 \\
Har 10 & 42.53 & 54.88 & 0.75 & 1.14 & 0.41 & 0.25 & 0.01 & 0.03 \\
Har 11 & 42.44 & 54.14 & 0.92 & 1.3 & 0.89 & 0.25 & 0.02 & 0.04 \\
Har 12 & 42.30 & 54.2 & 0.95 & 1.35 & 0.87 & 0.24 & 0.02 & 0.07 \\
\hline
\end{tabular}


Continued

\begin{tabular}{|c|c|c|c|c|c|c|c|c|}
\hline Har 13 & 41.51 & 54.3 & 1.5 & 1.37 & 0.91 & 0.31 & 0.02 & 0.08 \\
\hline Har 14 & 41.64 & 54.15 & 1.5 & 1.32 & 0.95 & 0.33 & 0.03 & 0.08 \\
\hline Har 15 & 41.64 & 54.19 & 1.53 & 1.35 & 0.89 & 0.3 & 0.02 & 0.08 \\
\hline Average value & 43.35 & 53.69 & 0.87 & 1.27 & 0.51 & 0.25 & 0.02 & 0.04 \\
\hline Hme 1 & 45.19 & 54 & 0.1 & 0.45 & 0.06 & 0.1 & 0.02 & 0.08 \\
\hline Hme 2 & 44.42 & 54.7 & 0.2 & 0.19 & 0.09 & 0.3 & 0.02 & 0.08 \\
\hline Hme3 & 43.37 & 55.8 & 0.24 & 0.33 & 0.06 & 0.1 & 0.01 & 0.09 \\
\hline Hme 4 & 43.19 & 55.9 & 0.3 & 0.21 & 0.08 & 0.2 & 0.03 & 0.09 \\
\hline Hme 5 & 44.44 & 54.6 & 0.1 & 0.35 & 0.07 & 0.3 & 0.02 & 0.12 \\
\hline Hme 6 & 43.82 & 55.2 & 0.11 & 0.44 & 0.09 & 0.2 & 0.02 & 0.12 \\
\hline Hme 7 & 43.12 & 55.1 & 0.31 & 1.1 & 0.05 & 0.2 & 0.02 & 0.1 \\
\hline Hme 8 & 43.47 & 54.2 & 0.63 & 1.12 & 0.06 & 0.4 & 0.02 & 0.1 \\
\hline Hme9 & 42.18 & 55.5 & 0.6 & 1.11 & 0.06 & 0.4 & 0.01 & 0.14 \\
\hline Hme 10 & 42.7 & 55.3 & 0.5 & 1.1 & 0.07 & 0.2 & 0.01 & 0.12 \\
\hline Hme 11 & 41.7 & 55.4 & 0.5 & 2.12 & 0.05 & 0.1 & 0.01 & 0.12 \\
\hline Hme 12 & 41.29 & 55.5 & 0.6 & 2.15 & 0.02 & 0.3 & 0.01 & 0.13 \\
\hline Hme 13 & 41.89 & 54.8 & 0.6 & 2.01 & 0.05 & 0.5 & 0.01 & 0.14 \\
\hline Hme 14 & 41.05 & 55.5 & 0.6 & 2.21 & 0.08 & 0.4 & 0.01 & 0.15 \\
\hline Hme 15 & 40.9 & 55.5 & 0.7 & 2.15 & 0.09 & 0.5 & 0.01 & 0.15 \\
\hline Average value & 42.85 & 55.13 & 0.41 & 1.14 & 0.07 & 0.28 & 0.02 & 0.12 \\
\hline Jer 1 & 43.64 & 52.3 & 2.21 & 1.57 & 0.24 & 0.01 & 0.01 & 0.02 \\
\hline Jer 2 & 44.72 & 51.4 & 2.18 & 1.36 & 0.22 & 0.02 & 0.02 & 0.08 \\
\hline Jer 3 & 43.76 & 51.2 & 2.11 & 2.62 & 0.21 & 0.02 & 0.01 & 0.07 \\
\hline Jer 4 & 42.77 & 52.18 & 2.12 & 2.61 & 0.22 & 0.02 & 0.01 & 0.07 \\
\hline Jer 5 & 43.26 & 52 & 1.89 & 2.55 & 0.2 & 0.02 & 0.02 & 0.06 \\
\hline Jer 6 & 40.76 & 54.22 & 2.18 & 2.54 & 0.21 & 0.02 & 0.01 & 0.06 \\
\hline Jer 7 & 41.92 & 53.11 & 2.13 & 2.51 & 0.22 & 0.05 & 0.01 & 0.05 \\
\hline Jer 8 & 40.66 & 53.72 & 2.13 & 3.12 & 0.22 & 0.08 & 0.01 & 0.06 \\
\hline Jer 9 & 41.38 & 53.2 & 1.94 & 3.11 & 0.23 & 0.07 & 0.02 & 0.05 \\
\hline Jer 10 & 41.57 & 52.83 & 2.17 & 3.11 & 0.21 & 0.04 & 0.01 & 0.06 \\
\hline Jer 11 & 40.22 & 54 & 2.31 & 3.12 & 0.21 & 0.07 & 0.01 & 0.06 \\
\hline Jer 12 & 39.62 & 53.95 & 1.92 & 4.13 & 0.23 & 0.08 & 0 & 0.07 \\
\hline Jer 13 & 39.54 & 54.04 & 2.11 & 4 & 0.22 & 0.02 & 0.01 & 0.06 \\
\hline Jer 14 & 40.04 & 53.55 & 1.97 & 4.16 & 0.21 & 0.02 & 0.01 & 0.04 \\
\hline Jer 15 & 40.38 & 53.14 & 2.18 & 3.96 & 0.21 & 0.07 & 0.01 & 0.05 \\
\hline Average value & 41.62 & 52.99 & 2.10 & 2.96 & 0.22 & 0.04 & 0.01 & 0.06 \\
\hline
\end{tabular}




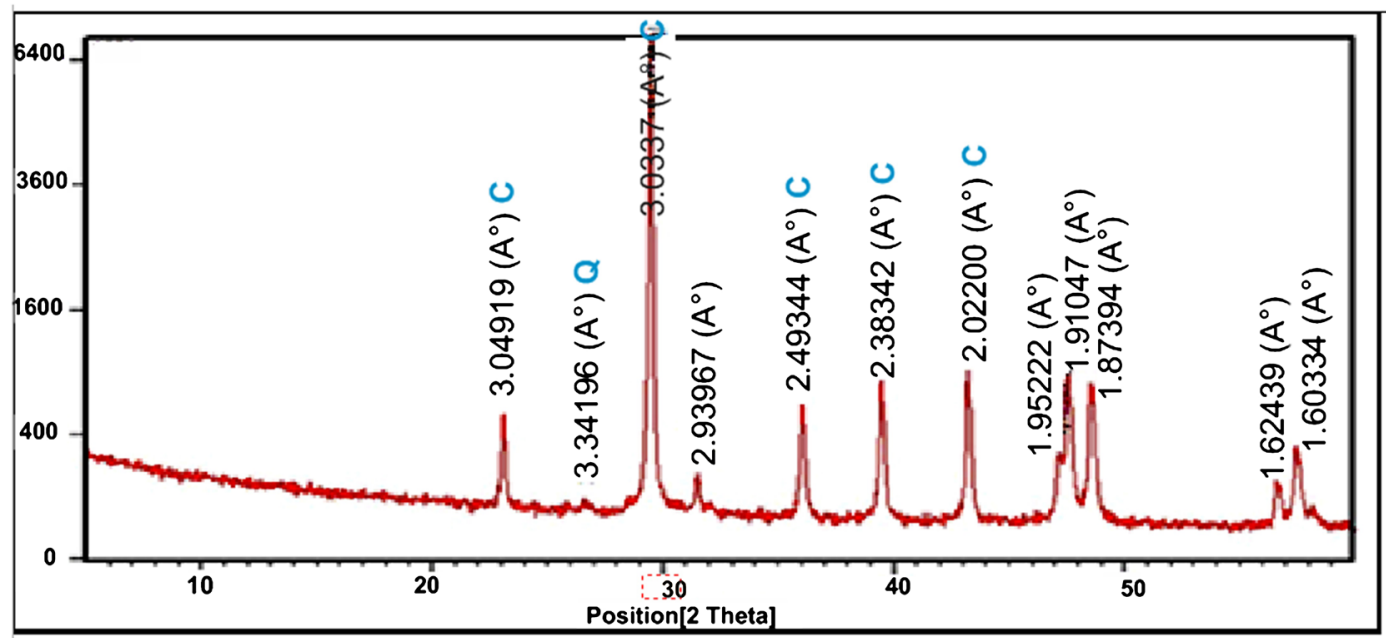

Figure 4. XRD patterns of the Aptian limestone of the Kef region (J.Hmeima).

\subsection{Gravimetric Characterization of the Aptian Limestones of the Kef Region}

The results of the gravimetric tests of Aptian limestones are presented in Table 3.

Gravimetric tests of Aptian limestones showed an acceptable flexural strength of $200 \mathrm{Kg} / \mathrm{cm}^{2}$ compared to a compressive strength of around $600 \mathrm{Kg} / \mathrm{cm}^{2}$ and sometimes greater than $850 \mathrm{Kg} / \mathrm{cm}^{2}$ (J. Jerissa). The impact wear values were greater than $28.44 \mathrm{~mm}$, while the ultrasonic coefficients oscillate around 5000 $\mathrm{m} / \mathrm{s}$, indicating the low porosity of this limestone (0.5\%). All samples showed a reduction in strength, probably caused by the cementing material, which in this case is calcite [22]. Other possible explanation is the reduction of surface particle energy [23], or a modification of particle binding due to interstitial pressure in poorly drained samples [24]. Analysis of the whiteness of limestones revealed a whiteness index of $83.22 \%$ and a chromatic tendency towards yellow (J. Harraba) or gray (J. Hmeima) or brown (J. Jerissa).

\subsection{Mechanical Characterization of Aptian Limestones of the Kef Region}

The results of the mechanical tests of Aptian limestones are presented in Table 4.

Aptian limestones in the Kef region have a variable Dry Micro Deval (MDS) coefficient about $32 \%$ for the outcrops of Harraba and Hmeima compared to a value of $23 \%$ for that of Jerissa. The Wet Micro Deval (MDH) coefficient was around 33\% for the Harraba and Hmeima deposits against a lower value for the Jerissa deposit. This is due to the presence of a ferruginous matrix acting as cement. The Los Angeles coefficient (LA) was about $25 \%$. The values of compressive strength have an interesting value for Jerissa limestone $\left(866 \mathrm{Kg} / \mathrm{cm}^{2}\right) \mathrm{com}$ pared to the acceptable values for the two others deposits. All limestones studied had an apparent density (MVA) and a Real density (MVR), varying from 2.66 $\mathrm{g} / \mathrm{cm}^{3}$ to $2.67 \mathrm{~g} / \mathrm{cm}^{3}$. The study of the limestone hardness in the Kef area (Figure 5) showed that all Aptian limestone deposits are able to cross the limit of hard 
field according to [25]. These results were confirmed by [26] who reported a hardness value rating of 7 to 8 and a compressive strength of 662 bars and a specific gravity of $2.54 \mathrm{~g} / \mathrm{cm}^{3}$.

Table 3. Gravimetric result of the Aptian limestone of the Kef region.

\begin{tabular}{|c|c|c|c|c|c|c|c|}
\hline Samples & $\begin{array}{c}\text { Flexion } \\
\text { (bars) }\end{array}$ & $\begin{array}{c}\text { Compression } \\
\text { (bars) }\end{array}$ & $\begin{array}{l}\text { Wear } \\
(\mathrm{mm})\end{array}$ & $\begin{array}{c}\text { Water } \\
\text { Absorption (\%) }\end{array}$ & $\begin{array}{l}\text { Density } \\
\left(\mathrm{g} / \mathrm{cm}^{3}\right)\end{array}$ & $\begin{array}{l}\text { Ultrasonic } \\
\qquad(\mathrm{m} / \mathrm{s})\end{array}$ & $\begin{array}{c}\text { Whiteness } \\
\text { index }\end{array}$ \\
\hline Har 1 & 200 & 620 & 36 & 0.9 & 2.46 & 4918 & 80.12 \\
\hline Har 2 & 205 & 620 & 37 & 0.93 & 2.45 & 4915 & 81.11 \\
\hline Har 3 & 205 & 630 & 37 & 0.92 & 2.5 & 4917 & 81.2 \\
\hline Har 4 & 210 & 650 & 36 & 0.94 & 2.5 & 4910 & 80.27 \\
\hline Har 5 & 205 & 644 & 36 & 0.95 & 2.5 & 4908 & 80.24 \\
\hline Har 6 & 205 & 680 & 34 & 0.14 & 2.5 & 4915 & 80.31 \\
\hline Har 7 & 212 & 685 & 34 & 0.15 & 2.5 & 4905 & 80.28 \\
\hline Har 8 & 215 & 695 & 33 & 0.17 & 2.51 & 4904 & 80.1 \\
\hline Har 9 & 216 & 700 & 33 & 0.2 & 2.52 & 4908 & 80.02 \\
\hline $\begin{array}{l}\text { Average } \\
\text { value }\end{array}$ & 208 & 658 & 35 & 0.59 & 2.49 & 4911 & 80.41 \\
\hline Hme 1 & 104 & 540 & 32 & 0.9 & 2.56 & 4865 & 79.23 \\
\hline Hme 2 & 105 & 550 & 32 & 0.94 & 2.55 & 4865 & 72.11 \\
\hline Hme 3 & 105 & 570 & 31 & 0.95 & 2.5 & 4865 & 73.28 \\
\hline Hme 4 & 106 & 570 & 31 & 0.94 & 2.5 & 4880 & 73.27 \\
\hline Hme 5 & 105 & 590 & 30 & 0.94 & 2.52 & 4833 & 73.74 \\
\hline Hme 6 & 105 & 600 & 30 & 0.95 & 2.54 & 4874 & 73.11 \\
\hline Hme 7 & 108 & 610 & 29 & 0.95 & 2.55 & 4880 & 73.78 \\
\hline Hme 8 & 108 & 620 & 29 & 1 & 2.54 & 4881 & 73.33 \\
\hline Hme 9 & 110 & 630 & 29 & 1 & 2.55 & 4882 & 73.68 \\
\hline $\begin{array}{l}\text { Average } \\
\text { value }\end{array}$ & 106 & 586 & 30 & 0.95 & 2.53 & 4870 & 73.95 \\
\hline Jer 1 & 200 & 760 & 28 & 0.6 & 2.5 & 5230 & 71.25 \\
\hline Jer 2 & 200 & 750 & 26 & 0.5 & 2.5 & 5235 & 70.13 \\
\hline Jer 3 & 201 & 770 & 27 & 0.62 & 2.5 & 5215 & 70.42 \\
\hline Jer 4 & 201 & 850 & 26 & 0.75 & 2.5 & 5250 & 70 \\
\hline Jer 5 & 202 & 810 & 26 & 1.05 & 2.52 & 5240 & 70.1 \\
\hline Jer 6 & 201 & 860 & 28 & 1.14 & 2.52 & 5220 & 70.5 \\
\hline Jer 7 & 204 & 940 & 27 & 1.35 & 2.52 & 5230 & 70.4 \\
\hline Jer 8 & 204 & 950 & 27 & 1.6 & 2.53 & 5240 & 70.2 \\
\hline Jer 9 & 205 & 990 & 28 & 1.6 & 2.53 & 5238 & 70.2 \\
\hline $\begin{array}{l}\text { Average } \\
\text { value }\end{array}$ & 202 & 853 & 27 & 1.02 & 2.51 & 5233 & 70.36 \\
\hline
\end{tabular}


Table 4. Geotechnical test results of limestone from the Kef region.

\begin{tabular}{|c|c|c|c|c|c|c|}
\hline Sample & $\begin{array}{c}\text { Dry Micro } \\
\text { Deval } \\
\text { (MDS) } \\
\%\end{array}$ & $\begin{array}{l}\text { Wet Micro } \\
\text { Deval } \\
(\mathrm{MDH}) \%\end{array}$ & $\begin{array}{c}\text { Los } \\
\text { Angeles } \\
\text { (LA)\% }\end{array}$ & $\begin{array}{l}\text { Compressive } \\
\text { Strength } \\
(\mathrm{Rc}) \mathrm{Kg} / \mathrm{cm}^{2}\end{array}$ & $\begin{array}{l}\text { Apparent } \\
\text { Density } \\
\text { (MVA) } \\
\mathrm{g} / \mathrm{cm}^{3}\end{array}$ & $\begin{array}{c}\text { Real Density } \\
\text { (MVR) } \\
\mathrm{g} / \mathrm{cm}^{3}\end{array}$ \\
\hline Har 1 & 33 & 35 & 25 & 625 & 2.66 & 2.65 \\
\hline Har 2 & 32 & 36 & 26 & 615 & 2.52 & 2.55 \\
\hline Har 3 & 34 & 38 & 26 & 620 & 2.6 & 2.63 \\
\hline Har 4 & 35 & 37 & 25 & 650 & 2.65 & 2.67 \\
\hline Har 5 & 34 & 37 & 26 & 645 & 2.65 & 2.68 \\
\hline Har 6 & 34 & 36 & 26 & 685 & 2.69 & 2.7 \\
\hline Har 7 & 33 & 35 & 24 & 685 & 2.73 & 2.75 \\
\hline Har 8 & 32 & 36 & 24 & 697 & 2.71 & 2.74 \\
\hline Har 9 & 32 & 35 & 23 & 700 & 2.74 & 2.75 \\
\hline $\begin{array}{c}\text { Average } \\
\text { value }\end{array}$ & 33 & 36 & 25 & 658 & 2.66 & 2.68 \\
\hline Hme 1 & 31 & 33 & 23 & 550 & 2.67 & 2.68 \\
\hline Hme 2 & 32 & 34 & 25 & 560 & 2.66 & 2.67 \\
\hline Hme 3 & 32 & 35 & 26 & 580 & 2.66 & 2.67 \\
\hline Hme 4 & 31 & 34 & 25 & 590 & 2.66 & 2.67 \\
\hline Hme 5 & 31 & 33 & 26 & 595 & 2.65 & 2.66 \\
\hline Hme 6 & 30 & 33 & 26 & 610 & 2.65 & 2.66 \\
\hline Hme 7 & 29 & 34 & 27 & 615 & 2.65 & 2.66 \\
\hline Hme 8 & 29 & 33 & 27 & 620 & 2.65 & 2.66 \\
\hline Hme 9 & 29 & 32 & 27 & 625 & 2.66 & 2.67 \\
\hline $\begin{array}{c}\text { Average } \\
\text { value }\end{array}$ & 30 & 33 & 25 & 593 & 2.66 & 2.67 \\
\hline Jer 1 & 19 & 22 & 22 & 770 & 2.64 & 2.65 \\
\hline Jer 2 & 20 & 24 & 22 & 755 & 2.65 & 2.65 \\
\hline Jer 3 & 25 & 26 & 23 & 795 & 2.65 & 2.65 \\
\hline Jer 4 & 24 & 26 & 23 & 860 & 2.64 & 2.65 \\
\hline Jer 5 & 24 & 26 & 25 & 825 & 2.61 & 2.65 \\
\hline Jer 6 & 25 & 26 & 25 & 875 & 2.65 & 2.65 \\
\hline Jer 7 & 26 & 27 & 24 & 965 & 2.65 & 2.66 \\
\hline Jer 8 & 26 & 28 & 24 & 970 & 2.64 & 2.7 \\
\hline Jer 9 & 26 & 29 & 22 & 980 & 2.65 & 2.71 \\
\hline $\begin{array}{c}\text { Average } \\
\text { value }\end{array}$ & 23 & 26 & 23 & 866 & 2.64 & 2.66 \\
\hline
\end{tabular}




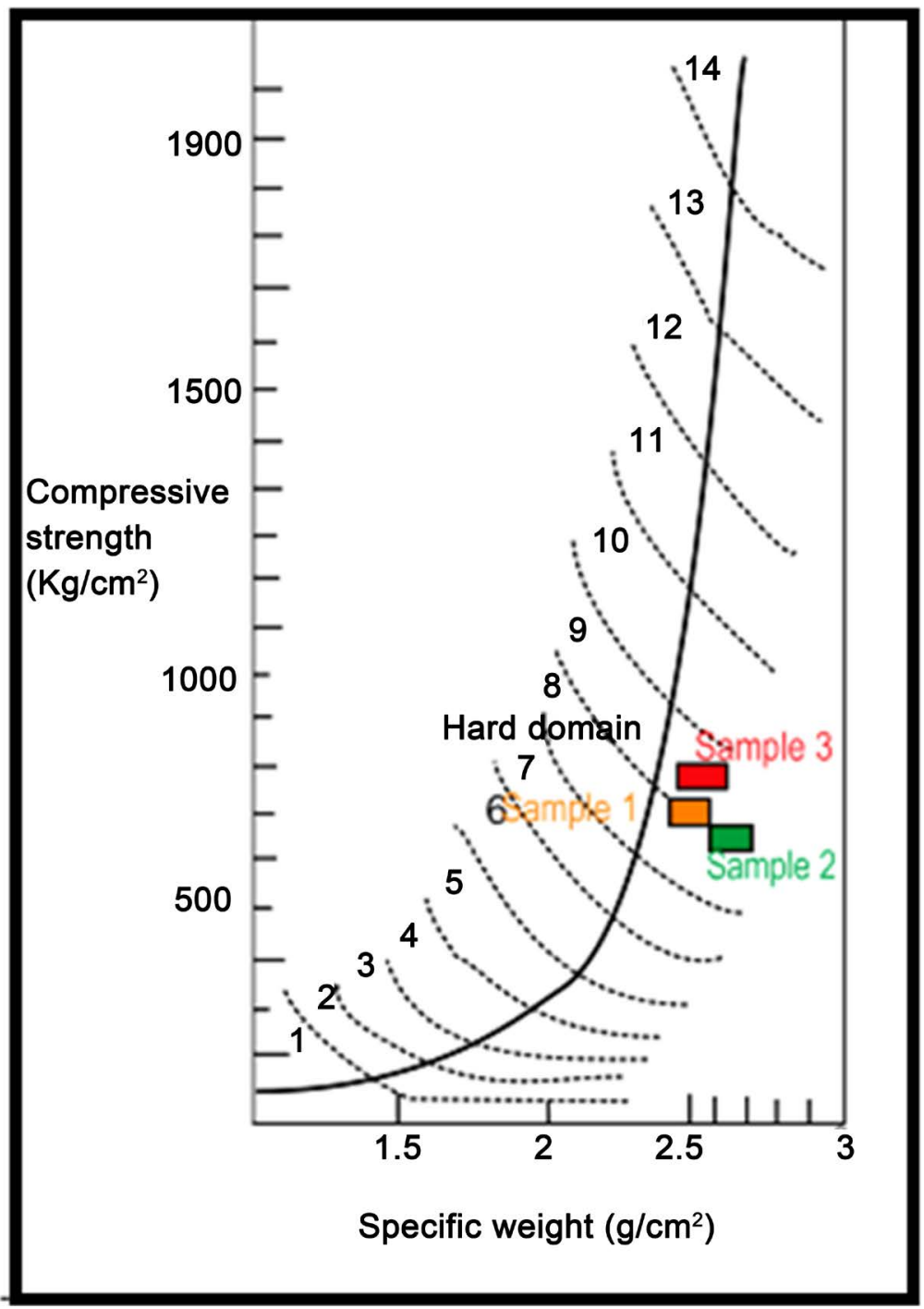

Figure 5. Hardness diagram of the Aptian limestone of the Kef area.

\subsection{Petrographic Study}

The petrographic examination of thin section representing the facies of the Aptian limestones (Figure 6) highlighted ferruginous inclusions in the cement and revealed the existence at least of two distinct phases of filling in karst. The karst affects the last calcareous bed of the Formation Serdj [27]. This bench is a wackestone-packstone limestone with orbitolina type (Mesorbitolina texana, Paracoskinolina tunisiana and Archaeoalveolina reicheili), milioles and rudists according to [28] [29]. The uniformity of these facies reveals a homogeneous and continuous sedimentation character. The karstic surface was found in our three study sites: Hameïma, Harraba and Jerissa. Unlike in the last 50 meters of the Serdj Formation of the Harraba deposit, we found ammonites Mellegueicerasechihaouiae, as well as poorly preserved Douvilleiceratidae. The presence of phosphate forms suggested that they are reworked and highlight an Aptian-Albian line [30]. 


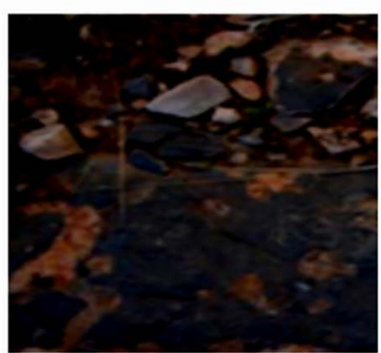

(a)

Jebel Hmeima sample

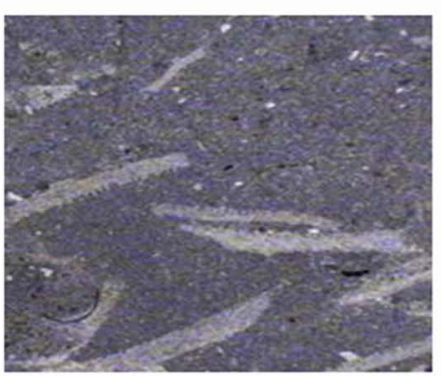

Orbitoline facies with

(b) abundant quartz

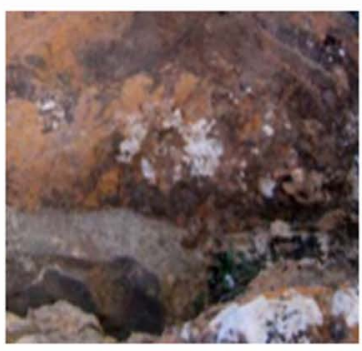

Jebel Jerissa sample

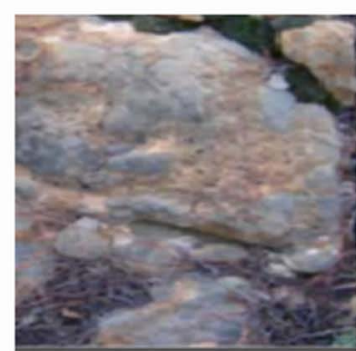

Jebel Harraba sample

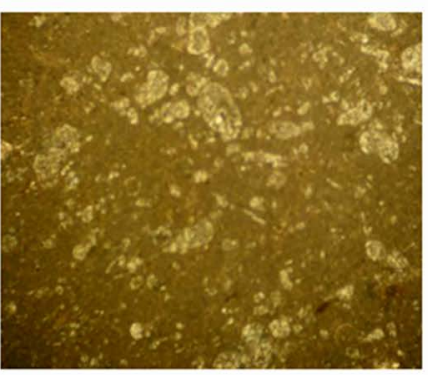

Karstified facies with orbitolines and fertigous

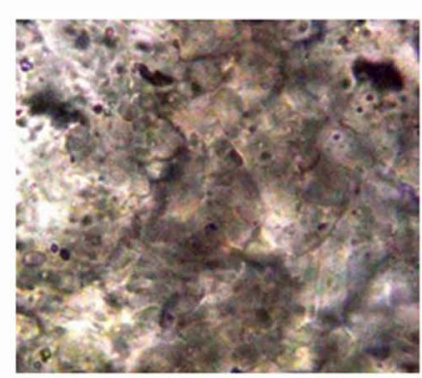

Karstified facies with dissolved shells

Figure 6. Petrographic facies of the Aptian limestones of the Kef region. (a) Limestone samples; (b) Microscopic Observation of each limestone sample (Grx5).

\subsection{Industrial Use of Limestone}

\subsubsection{Technological Characterization Parameters for Aggregates}

The specifications of the aggregates are based on their mechanical strength: Los Angeles and Micro-Deval [31]. The specifications (Table 5) of the aggregates take into account the different fields of use depending on the association with hydraulic hydrocarbon binder [32].

The characteristics of aggregates used in concrete (Table 6), as defined either by [33] [34], rely mainly on their mechanical characteristics such as the Los Angeles, Micro-Deval and the water absorption coefficient.

The cement is generally made from a mixture of limestone and marl fired at a temperature close to $1450^{\circ} \mathrm{C}$. The product thus formed is in the form of a module called Clinker, which, after fine grinding, will be added with a little addition (gypsum) to provide Portland cement. The quality criteria and permissible limits of the different cement components are shown in Table 6. Aptian Limestones of the Kef region can be used as a basis for the manufacture of cement CPA according Tunisian [35], but a restriction relative to their use for the production of hydraulic lime when their use is conditioned by chemicals corrections. In spite of their lithology, limestones have acceptable brightness index, however, its chromatic tendency towards yellow can play as a limiting factor for industrial use. The effect of oxidation by iron oxides is always felt. The calculation of the silica modulus (MS) and Alumino-ferric (MAF) modulus with the addition of 
Table 5. Specifications for road aggregates.

\begin{tabular}{|c|c|c|c|}
\hline \multicolumn{4}{|c|}{ Pavements type 4} \\
\hline \multicolumn{2}{|c|}{ Bituminous concrete } & \multicolumn{2}{|c|}{ Top rendering } \\
\hline LA & $\mathrm{MDH}$ & LA & $\mathrm{MDH}$ \\
\hline $25 \leq \mathrm{LA} \leq 30$ & $20 \leq \mathrm{MDH} \leq 25$ & $\leq 25$ & $\leq 20$ \\
\hline \multicolumn{4}{|c|}{ Pavements type T3 } \\
\hline \multicolumn{2}{|c|}{ Bituminous concrete } & \multicolumn{2}{|c|}{ Top rendering } \\
\hline LA & $\mathrm{MDH}$ & LA & $\mathrm{MDH}$ \\
\hline $20 \leq \mathrm{LA} \leq 25$ & $15 \leq \mathrm{MDH} \leq 20$ & $\leq 25$ & $\leq 20$ \\
\hline \multicolumn{4}{|c|}{ Pavements type T2 } \\
\hline \multicolumn{2}{|c|}{ Bituminous concrete } & \multicolumn{2}{|c|}{ Top rendering } \\
\hline LA & $\mathrm{MDH}$ & LA & $\mathrm{MDH}$ \\
\hline $25 \leq \mathrm{LA} \leq 30$ & $20 \leq \mathrm{MDH} \leq 25$ & $\leq 25$ & $\leq 20$ \\
\hline \multicolumn{4}{|c|}{ Pavements type $\mathrm{T} 1$} \\
\hline \multicolumn{2}{|c|}{ Bituminous concrete } & \multicolumn{2}{|c|}{ Top rendering } \\
\hline LA & $\mathrm{MDH}$ & LA & $\mathrm{MDH}$ \\
\hline $25 \leq \mathrm{LA} \leq 30$ & $20 \leq \mathrm{MDH} \leq 25$ & $\leq 25$ & $\leq 20$ \\
\hline \multicolumn{4}{|c|}{ Pavements type T0 } \\
\hline \multicolumn{2}{|c|}{ Bituminous concrete } & \multicolumn{2}{|c|}{ Top rendering } \\
\hline LA & $\mathrm{MDH}$ & LA & $\mathrm{MDH}$ \\
\hline $\mathrm{LA} \leq 25$ & $\mathrm{MDH} \leq 20$ & $\leq 20$ & $\leq 10$ \\
\hline
\end{tabular}

Table 6. Criteria for the use of aggregates in ordinary concrete and cement.

\begin{tabular}{|c|c|c|c|c|c|c|}
\hline \multicolumn{7}{|c|}{ Concrete } \\
\hline LA & $\mathrm{MDH}$ & Water Absorption & $\begin{array}{l}\text { Silicic Modulus } \\
\text { (MS) }\end{array}$ & $\begin{array}{l}\text { Alumino-Ferric } \\
\text { modulus (MAF) }\end{array}$ & & \\
\hline$\leq 40$ & $\leq 35$ & 0.5 & $2.4<\mathrm{MS}<2.7$ & $1.5<\mathrm{MAF}<2.5$ & & \\
\hline $\mathrm{CaO}$ & $\mathrm{MgO}$ & $\mathrm{Al}_{2} \mathrm{O}_{3}$ & $\mathrm{Fe}_{2} \mathrm{O}_{3}$ & $\mathrm{SiO}_{2}$ & & \\
\hline$>51$ & $<2$ & $<1$ & $<1$ & $<6$ & & \\
\hline \multicolumn{7}{|c|}{ White Cement } \\
\hline MS & MAF & DS & & & & \\
\hline$\geq 2.4$ & $\leq 2$ & $\geq 0.95$ & & & & \\
\hline \multicolumn{7}{|c|}{ Hydraulic lime } \\
\hline MS & DS & $\mathrm{IH}$ & & & & \\
\hline$\geq 2.4$ & $\geq 0.95$ & $0.45<\mathrm{IH}<1$ & & & & \\
\hline \multicolumn{7}{|c|}{ Quick lime } \\
\hline $\mathrm{CaCO}_{3}$ & MS & MAF & DS & & & \\
\hline$>98$ & $\geq 2.4$ & $\leq 2$ & $\geq 0.95$ & & & \\
\hline \multicolumn{7}{|c|}{ Portland Cement } \\
\hline $\mathrm{CaO}$ & $\mathrm{MgO}$ & $\mathrm{Al}_{2} \mathrm{O}_{3}$ & $\mathrm{Fe}_{2} \mathrm{O}_{3}$ & $\mathrm{SiO}_{2}$ & MS & MAF \\
\hline$>51$ & $<2$ & $<1$ & $<1$ & $<6$ & $2.4<\mathrm{MS}<2.7$ & $1.5<\mathrm{MAF}<2.5$ \\
\hline
\end{tabular}


the marls of the region give satisfactory results. For the field of concrete the carbonate outcrops find their place despite their inter-variability.

\subsubsection{Criteria for Chemical and Agricultural Use of Limestones}

Calcium carbonates and lime, derived from limestone, are widely used in agriculture, both as an amendment or soil corrector, as well as in the processing of agricultural products (sugar manufacture), animal, and human feed. The selection criteria for the use of limestone are presented in Table 7. For certain uses other criteria are required such as the whiteness at least equal to $85 \%$ for the fillers and the compressive strength $>400 \mathrm{Kg} / \mathrm{cm}^{2}$ for the rocks dedicated to lime.

All the carbonate deposits studied are favorable for use in the field of chemistry. Their calcium carbonate content and the chemical composition of all the calcareous deposits reveal an interesting mineralogical purity and homogeneity. The $\mathrm{CaCO}_{3}$ content greatly exceeds $95 \%$. This use is strongly conditioned by the variability of the values recorded which is due to the degree of recrystallization and the limestone porosity in relation to the Grain dimensions which form the carbonated cement.

Table 7. Chemical criteria required according to the use of limestone [32].

\begin{tabular}{|c|c|c|c|c|c|}
\hline \multicolumn{6}{|c|}{ Steel industry } \\
\hline $\mathrm{CaO}$ & $\mathrm{MgO}$ & $\mathrm{Al}_{2} \mathrm{O}_{3}$ & $\mathrm{Fe}_{2} \mathrm{O}_{3}$ & $\mathrm{SiO}_{2}$ & \\
\hline$>51$ & $<2$ & $<1$ & $<1$ & $<6$ & \\
\hline \multicolumn{6}{|c|}{ Chemical industry } \\
\hline $\mathrm{CaO}$ & $\mathrm{MgO}$ & $\mathrm{Al}_{2} \mathrm{O}_{3}$ & $\mathrm{Fe}_{2} \mathrm{O}_{3}$ & $\mathrm{SiO}_{2}$ & $S$ \\
\hline$>50$ & $>1$ & $<0.2$ & $<0.3$ & $\varepsilon$ & $<0.1$ \\
\hline \multicolumn{6}{|c|}{ Charge } \\
\hline $\mathrm{CaO}$ & $\mathrm{MgO}$ & $\mathrm{Al}_{2} \mathrm{O}_{3}$ & $\mathrm{Fe}_{2} \mathrm{O}_{3}$ & $\mathrm{SiO}_{2}$ & \\
\hline$>55$ & & $<0.2$ & $<0.2$ & $\varepsilon$ & \\
\hline \multicolumn{6}{|c|}{ Flue gas treatment } \\
\hline $\mathrm{CaO}$ & $\mathrm{MgO}$ & $\mathrm{Al}_{2} \mathrm{O}_{3}$ & $\mathrm{Fe}_{2} \mathrm{O}_{3}$ & $\mathrm{SiO}_{2}$ & \\
\hline$>51$ & $<1.5$ & & & $<0.1$ & \\
\hline \multicolumn{6}{|c|}{ Glassware } \\
\hline $\mathrm{CaO}$ & $\mathrm{MgO}$ & $\mathrm{Al}_{2} \mathrm{O}_{3}$ & $\mathrm{Fe}_{2} \mathrm{O}_{3}$ & $\mathrm{SiO}_{2}$ & \\
\hline$>55$ & & $<0.7$ & $<0.1$ & $<0.3$ & \\
\hline \multicolumn{6}{|c|}{ Calcium carbonate } \\
\hline $\mathrm{CaO}$ & $\mathrm{MgO}$ & $\mathrm{Al}_{2} \mathrm{O}_{3}$ & $\mathrm{Fe}_{2} \mathrm{O}_{3}$ & $\mathrm{SiO}_{2}$ & \\
\hline$>55$ & $<0.59$ & 0.045 & 0.04 & 0.12 & \\
\hline \multicolumn{6}{|c|}{ Agriculture } \\
\hline Whiteness & $\begin{array}{l}\text { compressive } \\
\text { strength }\end{array}$ & & & & \\
\hline$>85$ & $>400$ & & & & \\
\hline
\end{tabular}




\subsubsection{Possibilities of Industrial Use of the Aptian Limestone Deposits of the Kef Area}

The use of limestone in marble industry depends on numerous parameters. The degree of importance relative to each technical parameter of the marble stones studied in relation to the various use in the field of construction was presented in Table 8.

The Aptian limestone of the Kef region can be used in various industrial fields such as the marble quarry sector. Since all deposits are favorable for use as a marble stone, a deposit study has objectified the estimation of the volume and dimensions of the blocks (Figure 7) that could be extracted according to the

Table 8. Industrial parameters for use in marble [36].

\begin{tabular}{|c|c|c|c|c|c|c|c|}
\hline & $\begin{array}{l}\text { Apparent } \\
\text { density } \\
\left(\mathrm{g} / \mathrm{cm}^{3}\right)\end{array}$ & $\begin{array}{c}\text { Water } \\
\text { absorption } \\
(\%)\end{array}$ & $\begin{array}{l}\text { Compressive } \\
\text { strength (bar) }\end{array}$ & $\begin{array}{l}\text { Bending strength } \\
\text { (bar) }\end{array}$ & $\begin{array}{l}\text { Shock value } \\
(\mathrm{cm})\end{array}$ & $\begin{array}{l}\text { Wear } \\
\text { value } \\
(\mathrm{mm})\end{array}$ & $\begin{array}{l}\text { Ultrasonic } \\
\qquad(\mathrm{m} / \mathrm{s})\end{array}$ \\
\hline Exterior Siding & - 0 & 0 & 0 & 000 & & 0 & 0 \\
\hline Interior Siding & 0 & ○ & - & - & & & 0 \\
\hline Paving Outside & 0 & 0 & 0 & 0 & 000 & 000 & 0 \\
\hline $\begin{array}{l}\text { Interior Paving and } \\
\text { stair Lining }\end{array}$ & ○ 0 & 0 & - & $\bullet \bullet$ & 000 & 000 & 0 \\
\hline Suspended Staircase & 0 & $\mathbf{0}$ & 0 & 000 & 000 & 000 & 0 \\
\hline
\end{tabular}

O: Very important; O: Important; 0 : Low importance.
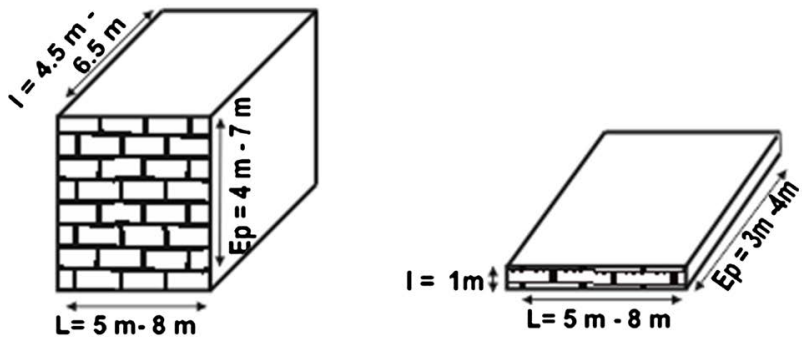

Marble shape's samples (Jebel Jerissa)
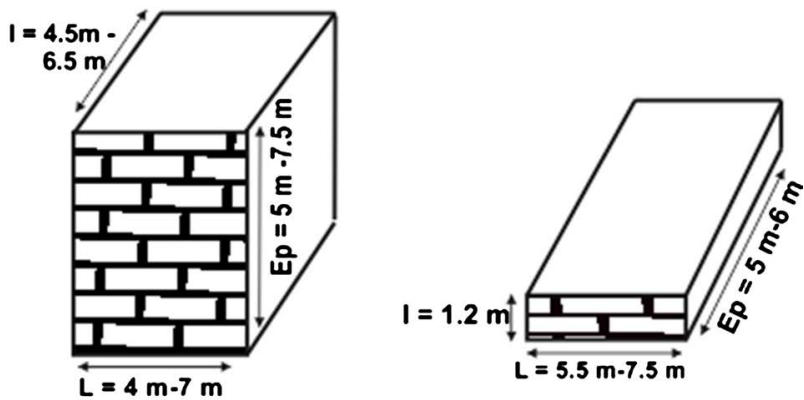

Marble shape's samples (Jebel Harraba / Jebel Hmeima)

Figure 7. Block Diagram of the dimensions of the marble blocks extracted from the Aptian limestone. 
Table 9. Dimensions of marble blocks as a function of fracture index.

\begin{tabular}{cccccccc}
\hline & $\begin{array}{c}\text { Minimal } \\
\text { Thickness } \\
(\mathrm{m})\end{array}$ & $\begin{array}{c}\text { Maximum } \\
\text { Thickness } \\
(\mathrm{m})\end{array}$ & $\begin{array}{c}\text { Fracture } \\
\text { Index (IF) }\end{array}$ & $\mathrm{L}(\mathrm{m})$ & $\mathrm{l}(\mathrm{m})$ & $\begin{array}{c}\text { Minimum } \\
\text { Volume } \\
\text { Vm }\left(\mathrm{m}^{3}\right)\end{array}$ & $\begin{array}{c}\text { Maximum } \\
\text { Volume VM } \\
\left(\mathrm{m}^{3}\right)\end{array}$ \\
\hline Hme & 1.2 & 5.5 & 0.1 & 7 & 6.5 & 54.6 & 250.25 \\
Har & 1.2 & 5 & 0.1 & 7 & 5.5 & 46.2 & 192.5 \\
Jer & 0.8 & 5.5 & 0.114 & 8 & 5 & 32 & 220 \\
\hline
\end{tabular}

fracturing density (length, Width, thickness) recorded. [37] suggests that marble does not exist anywhere in Tunisia. However, slightly metamorphosed and/or recrystallized carbonates, giving good polish and good color, were able to impose themselves on the national and international market. The work of these authors was able to distinguish clearly lower gravimetric characteristics for the Eocene limestone of Tunisia (Kesra Marble) with a porosity ranging from 1.6\% to $4 \%$, a compressive strength ranging from $450 \mathrm{Kg} / \mathrm{cm}^{2}$ to $1250 \mathrm{Kg} / \mathrm{cm}^{2}$ and a water absorption value varying from $0.25 \%$ to $1.7 \%$. The extracted blocks can have a volume ranging from $32 \mathrm{~m}^{3}$ to $250 \mathrm{~m}^{3}$ (Table 9).

\section{Conclusion}

The study of the carbonate deposits of the Kef region has objectified the Aptian limestones. The calcium carbonate content and the chemical composition of all the calcareous deposits show a very high purity and mineralogical homogeneity. The geotechnical resistance tests showed that limestones are compact and massive. These results are confirmed by gravimetric tests. Despite its lithology described as a pakestone-wakestone limestone, the Aptian limestones of the Kef region have an acceptable whiteness index; however, its chromatic tendency towards yellow may be a limiting factor for industrial use. The effect of oxidation by iron oxides is always felt. The variability of the geotechnical and gravimetric values is due to the degree of recrystallization and to the porosity of the limestones and to the fineness of the grains that form the carbonate cement. The limestones offer a multitude of industrial use in the field of construction (marble, cement, calcium carbonate), in the infrastructure (aggregates) and in the field of chemistry and the siderurgy. This study will help to understand the behavior of Aptian calcareous limestone for different industrial use fields, however more detailed studies should be undertaken and data set is required to launch economic projects.

\section{Acknowledgements}

Our warmest thanks go out to all the staff of the Concrete laboratory of the Technical Center for Ceramic, Glass and Construction Materials-CTMCCV and the cement quality laboratory of the Oum El Kélil cement company-CIOK.

\section{Conflicts of Interest}

The authors declare no conflicts of interest regarding the publication of this paper. 


\section{References}

[1] Pervinquière, L. (1903) Geological Survey of Central Tunisia. PhD Thesis, University of Paris, De Rudeval, Paris.

[2] Dubourdieu, G. (1956) Geological Study of the Ouenza Region (Algerian-Tunisian Borders). Publications of the Service of the Geological Map of Algeria (New Series), Bulletin $\mathrm{n}^{\circ} 10,659 \mathrm{p}$.

[3] Burollet, P.F. (1956) Contribution to the Stratigraphic Study of Central Tunisia. Annals of Mining and Geology, $345 \mathrm{p}$.

[4] M'Rabet, A. (1981) Stratigraphy, Sedimentation and Carbonate Diagenesis of the Lower Cretaceous Series of Central Tunisia. Doctor Thesis, University of Paris-Sud, Orsay, $540 \mathrm{p}$.

[5] Sainfeld, P.F. (1956) Explanatory Note of the Geological Map at $1 / 50,000^{\circ}$ of Tadjerouine (51). Department of Mines, Industry and Energy, Tunis, $36 \mathrm{p}$.

[6] Casey, R., Bayliss, H.M. and Simpson, M.I. (1998) Observations on the Lithostratigraphy and Ammonite Succession of the Aptian (Lower Cretaceous) Lower Greensand of Chale Bay, Isle of Wight, UK. Cretaceous Research, 19, 511-535.

https://doi.org/10.1006/cres.1997.0105

[7] Chikhaoui, M., Turki, M.M. and Delteil, J. (1991) Testimonies of the Structurogenesis of the Tethyan Margin in Tunisia, the Jurassic terminal-Cretaceous (Kef Region, Northern Tunisia). Mediterranean Geology, Marseille, 18, 125-133.

[8] Chihaoui, A. (2010) The Albian Transgression in the Region of Tajerouine in Central Tunisia: Stratigraphy, Sedimentology and Syn-Sedimentary Tectonics. Mineralogy. Universite Joseph-Fourier, Grenoble.

[9] Ben M’Barek Jemaii, M. (2015) Late Cretaceous and Palaeocene Clays of the Northern Tunisia: Potential Use for Manufacturing Clay Products. Arabian Journal of Geosciences, 8, 11135-11148. https://doi.org/10.1007/s12517-015-1897-1

[10] Standard NF-B 10-614 (1999) Compression Tests on Marble Specimen.

[11] Standard NF-B 10-621 (1999) Bending Tests on Marble Specimen.

[12] Standard NF EN 14617-9 (2005) Agglomerated Stone-Test Methods-Part 4: Determination of Wear Resistance.

[13] Standard NF-B 10-508 (1973) Calcareous Stones-Metal Disk Wear Test.

[14] Standard NF-B 10-615 (1999) Determination of the Porosity of Rocks.

[15] Standard NF-B 10-505 (1973) Calcareous Stones-Measurement of the Propagation Velocity of Sound (Longitudinal Waves).

[16] Standard NF EN 932-1 (1996) Tests for Determining the General Properties of Aggregates. Sampling Method.

[17] Standard NF EN 1097-2 (2010) Tests for Determining the Mechanical and Physical Characteristics of Aggregates Part 2: Methods for Determining Resistance to Fragmentation.

[18] Standard NF EN 1097-1 (2011) Tests for Determining the Mechanical and Physical Characteristics of Aggregates Part 1: Determination of Wear Resistance (Micro-Deval).

[19] Standard NF EN 1097-6 (2014) Tests for Determining the Mechanical and Physical Characteristics of Aggregates Part 6: Determination of Actual Density and Water Absorption Coefficient.

[20] Folk, R.L. (1974) The Natural History of Crystalline Calcium Carbonate: Effect of Magnesium Content and Salinity. Journal of Sedimentary Petrology, 44, 40-53. 
[21] Dunham, R.J. (1962) Classification of Carbonate Rocks According to Depositional Texture. In: Classification of Carbonate Rocks Symposium, American Association of Petroleum Geologists, Tulsa, 108-121.

[22] Jouirou, M. (1981) Geological and Geochemical Study of Sediments in the Kef Region. (North-West of Tunisia) Doctoral Thesis in Geology and Application to the Marine Domain, Faculty of Sciences of Tunis, Tunis, 200.

[23] Pugh, S.F. (1967) The Fracture of Brittle Materials. British Journal of Applied Physics, 18, 129-161. https://doi.org/10.1088/0508-3443/18/2/301

[24] Attewell and Farmer (1974) Fatigue Behavior of Rock. International Journal of Rock Mechanics and Mining Sciences \& Geomechanics Abstracts, 10, 1-9.

[25] Standard NFB-10-001 (1975) Quarrying and Dredging Products-Materials-Limestone Stones.

[26] Ouertani, A. (2004) Study of the Sedimentary Series of Structures and Useful Substances of Jebal el Hout-Jerissa.

[27] Dumont, T., Arnaud, H., Arnaud, A. and Zghal, I. (2005) Jebel Hameima-Upper Aptian Tilted Blocks: Paleotectonic Setting, Karstification and Mineralization.

[28] Peybernes, B. (1979) The Brachiopods of the Dogger of the Pyrenees Navarro-Languedociennes (Biostratigraphy and Paleontology). Documents of the Laboratories of Geology of the Faculty of Sciences of Lyon, 76, 23-133.

[29] Zghal, I. (1994) Microbiostratigraphic Study of the Lower Cretaceous of Central Western Tunisia (Kasserine-Sbeitla and Tadjerouine Region). Geological Thesis, $393 \mathrm{p}$.

[30] Jaillard, E., Latil, J.-L., Echihaoui, A. and Zghal, I. (2005) Albian Sedimentation in the Tadjerouine Area. Tour Guidebook, Aptian-Turonian Events in Central Tunisia. Geology Alpine, ser. Spec. 5, 105-124.

[31] Berton, Y. and Le Berre, P. (1983) Guide to Prospecting Quarry Materials. BRGM Editions, Manuals and Methods No. 5.

[32] Gaied, M. (1996) Doctoral Thesis, Geological and Geotechnical Study of Eocene Useful Materials from the North-Eastern Edge of the Kasserine Palaeo-Relief (Central Tunisia). Faculty of Sciences of Tunis, 135.

[33] Standard DIN 18301 (2015) German Specification for Building Work (VOB)—Part C: General Technical Clauses for the Execution of Building Work.

[34] Dupain, R., et al. (1980) Aggregate, Soils, Cement and Concretes, Characterization of Civil Engineering Materials by Laboratory Tests. 2nd Edition, 80.

[35] Standard NT 47.01 (2005) Cement, Part I, Composition, Specifications and Conformity Criteria for Common Cements.

[36] Ben Salah, I. (2003) Study of Upper Cretaceous Substances of Central Tunisia-Makthar Region. Memory of DEA, Faculty of Sciences of Tunis, 70.

[37] Chaabani, F., Gaied, B.H., Ali, M., Zagrani, M.F. and Taamallah, N. (2000) The Marble Stones of Tunisia. Annals of Mining and Geology, No. 38, 112. 